\title{
Editorial: Greenhouse Gas Emissions Mitigation From Agricultural and Horticultural Systems
}

\author{
Dietmar Schwarz ${ }^{1}$, Matthew Tom Harrison ${ }^{2 \star}$ and Nikolaos Katsoulas ${ }^{3}$ \\ ${ }^{1}$ Leibniz Institute of Vegetable and Ornamental Crops (IGZ), Großbeeren, Germany, ${ }^{2}$ Agricultural Systems Centre, Tasmanian \\ Institute of Agriculture, University of Tasmania, Hobart, TAS, Australia, ${ }^{3}$ School of Agricultural Sciences, University of \\ Thessaly, Volos, Greece
}

Keywords: avoidance, carbon dioxide removal, nitrous oxide $-\mathrm{N}_{2} \mathrm{O}$, methane $-\mathrm{CH}_{4}$, soil carbon, fertilizer, displacement, net-zero emissions

\section{Editorial on the Research Topic}

\section{Greenhouse Gas Emissions Mitigation From Agricultural and Horticultural Systems}

Global geopolitics were harmonized at COP26 when more than 150 countries pledged to the Glasgow Climate Pact, resulting in unified aspirations to constrain global average temperature rise to $1.5^{\circ} \mathrm{C}$ and well below $2^{\circ} \mathrm{C}$ by 2050 (UNFCCC, 2021). Achievement of this goal demands urgent, deep and sustained reductions in global greenhouse gas (GHG) emissions, with threshold targets of $45 \%$ by 2030 (relative to 2010) and net zero by mid-century (UNFCCC, 2021). With agriculture, forestry and other land use (AFOLU) contributing $24 \%$ of global GHG emissions each year, AFOLU

OPEN ACCESS

Edited and Reviewed by: Stephen Whitfield

University of Leeds, United Kingdom

*Correspondence:

Matthew Tom Harrison matthew.harrison@utas.edu.au orcid.org/0000-0001-7425-452X

Specialty section:

This article was submitted to

Climate-Smart Food Systems, a section of the journal

Frontiers in Sustainable Food Systems

Received: 24 December 2021

Accepted: 25 January 2022

Published: 03 March 2022

Citation:

Schwarz D, Harrison MT and Katsoulas N (2022) Editorial: Greenhouse Gas Emissions Mitigation From Agricultural and Horticultural doi: 10.3389/fsufs.2022.842848 represents the second largest contributor to global GHG emissions after the energy sector (IPCC, 2014).

Predominant GHG emissions from agri-food systems include methane $\left(\mathrm{CH}_{4}\right)$, nitrous oxide $\left(\mathrm{N}_{2} \mathrm{O}\right)$, and carbon dioxide $\left(\mathrm{CO}_{2}\right)$ from livestock, savanna and crop residue burning, soil respiration and cultivation, fertilizer and lime application, burning of electricity and fuel (Harrison et al., 2016). Direct GHG emissions are generated from livestock enteric fermentation (48\%) and excreta $(22 \%)$, crop production systems with nitrogen $(\mathrm{N})$ fertilizers $(10 \%)$, and rice paddy cultivation (11.5\%) (FAO, 2021). The magnitude of global AFOLU GHG emissions suggests that the development of skills, practices, and technologies for GHG emissions mitigation must be foremost priorities when proposing any systemic or transformational innovation for adaptation to the climate crisis (Ho et al., 2014; Alcock et al., 2015; Chang-Fung-Martel et al., 2017). The diversity of processes and GHGs per se from AFOLU does however provide significant latitude for GHG mitigation through manifold avenues, including carbon dioxide removal (CDR), enhanced reduction, avoidance, and/or displacement (Smith et al., 2008).

This Research Topic documents scientific advances in measurement protocols for field or greenhouse gas experimentation, together with improved modeling that allows upscaling and extrapolation of field measurements. Three papers focus on milk production in dairy systems (housed or grazing), five papers examine plant production systems, and one paper reviews the literature, synthesizing opportunities for strategic GHG emissions mitigation in grazing systems. For example, Häfner et al. fastidiously distinguish between organic- $\mathrm{N}$ and ammonium- $\mathrm{N}$ as potential $\mathrm{N}$ sources for denitrification in the field, while Prangbang et al. measure and model the regional applicability of alternate wetting and drying (AWD) of rice paddies as prospective pathways for methane mitigation. Sokolov et al. quantify the effects caused by acidifying manure inoculum on the $\mathrm{CH}_{4}, \mathrm{~N}_{2} \mathrm{O}$, and ammonia $\left(\mathrm{NH}_{3}\right)$ emissions from stored dairy manure by targeting 
Methyl Coenzyme M Reductase A genes, as well as bacterial abundance using real-time qPCR. Finally, March et al. compute the carbon footprints of milk production systems using Life Cycle Assessments (LCA). They demonstrate the importance of allocation method, livestock genetics and management in the attribution of GHG emissions. The same authors also examined the effects of nutritional quality on the carbon footprint of novel and conventional dairy systems. Differential allocation methods resulted in GHG emissions ranging from 0.95 to $3.79 \mathrm{~kg} \mathrm{CO} 2 \mathrm{e} / \mathrm{kg}$ fat and protein corrected milk, indicating the importance of quantifying footprints using multiple metrics, similar to work shown for cattle and sheep production systems elsewhere (Harrison et al., 2014; Alcock et al., 2015).

Durango Morales et al. demonstrate a clear need for development of site-specific $\mathrm{N}_{2} \mathrm{O}$ emission factors (EF), as opposed to the more generic and granular Tier $1 \mathrm{EF}$ used by the IPCC. They show that EFs can be reduced by decreasing urine deposits, by limiting $\mathrm{N}$ inputs to pastures. More strategic planning of nitrogenous fertilizer type (urea, green urea, slow release etc.), timing, rate and placement shown in other dairy studies (Christie et al., 2018, 2020) has similarly shown that improved use of $\mathrm{N}$ fertilizer reduces urea $\mathrm{N}$ in the milk.

Emissions of $\mathrm{CH}_{4}, \mathrm{~N}_{2} \mathrm{O}$, and $\mathrm{NH}_{3}$ from liquid manure storages can be substantially reduced $(>70 \%)$ by acidifying manure, however this usually comes with high financial costs (Sommer et al., 2017). Sokolov et al. propose acidification of only manure inoculum. To determine the feasibility of this idea, they elicit functional mechanisms by measuring methanogenic activity and abundance using Methyl Coenzyme M Reductase A (mcrA), a gene and transcript which encodes a subunit of the key enzyme that catalyzes the final step of methanogenesis. Sokolov et al. (2020) also used quantitative real-time PCR to quantify bacterial abundance using the $16 \mathrm{~S}$ rRNA gene. They found that the $38-77 \%$ mitigation of $\mathrm{CH}_{4}$ was caused by disruption of the mcrA gene and transcript abundance, while $\mathrm{NH}_{3}$ and $\mathrm{N}_{2} \mathrm{O}$ emissions were reduced by $33-73 \%$ by acidyfing inoculum. The authors concluded that future studies should test lower acid rates and less frequent acidification to further lower financial costs in commercial settings.

In a review of $\mathrm{CH}_{4}$ and $\mathrm{N}_{2} \mathrm{O}$ emissions from animal manure, Rivera and Chará converse that emissions depend on multiple factors and are highly variable, implying that "one size fits all" solutions are problematic at best, similar to observations by Durango Morales et al. Rivera and Chará found that promising options for reducing emissions from livestock manure include manipulation of livestock diet nutritional quality, [where practical] implementation of silvopastoral systems, use of nitrogen fixing plants, and management approaches for improving soil health, carbon storage and seasonal ground cover.

It is well-known that synthetic nitrogenous fertilizers in intensive agricultural and horticultural production systems are a key source of GHG emissions (Christie et al., 2018, 2020). Of the studies we are aware of, Karlowsky et al. is the first to measure how $\mathrm{N}$ fertilizers impact $\mathrm{N}_{2} \mathrm{O}$ in hydroponic greenhouse production. They showed that $\mathrm{N}_{2} \mathrm{O}$ emissions from tomato and cucumber account for 2.3 and $1.5 \mathrm{~kg} \mathrm{ha}^{-1} \mathrm{yr}^{-1}$, respectively, lower than previously measured in laboratory experiments (Daum and Schenk, 1996). Kitamura et al. show that organic fertilizers (viz. manure and digestive fluid) had both positive effects on soil carbon stocks and caused greater reduction in $\mathrm{N}_{2} \mathrm{O}$ relative to synthetic $\mathrm{N}$ fertilizer. By using organic fertilizers from legume-based crops grown for green $\mathrm{N}$ and incorporating the material into the soil, Singh et al. report that (i) postcultivation $\mathrm{N}_{2} \mathrm{O}$ emissions can be greater from non-legume green $\mathrm{N}$ crops compared with legume green $\mathrm{N}$ crops due to greater biomass productivity of the former, and (ii) emissions of $\mathrm{N}_{2} \mathrm{O}$ could be mitigated by removing biomass of the green $\mathrm{N}$ crop for use as forage. Häfner et al. find that digestate application mainly resulted in $\mathrm{N}_{2} \mathrm{O}$ emissions derived from existing soil $\mathrm{N}$ stocks, rather than $\mathrm{N}$ applied. Collectively, these findings suggest that comprehensive consideration of all plant genetic, environmental and management factors is necessary to help guide the development of best management practices regarding fertilizer use.

Water management is another tactical tool allowing reduction of GHG emissions from irrigated cropping systems. Alternate wetting and drying (AWD) was proposed by Prangbang et al. as a management approach that would enable both water savings and methane mitigation from rice paddy fields. However, future studies of this type should also examine the implications of tradeoffs and co-benefits associated with GHG mitigation options (Harrison et al., 2011). Using AWD can result in greater rice biomass production and this requires greater $\mathrm{N}$ fertilization, ensuing increase in $\mathrm{N}_{2} \mathrm{O}$ emissions (Christie et al., 2014). Such $\mathrm{N}_{2} \mathrm{O}$ increases may well offset any mitigation caused by reduced $\mathrm{CH}_{4}$ emissions, underscoring the need to holistically explore multiple GHG emissions in a closed systems, using multiple metrics (Harrison et al., 2012, 2021).

This Research Topic provides several promising avenues for sustained-and in some cases, substantial-reduction of GHG emissions, in line with aspirations posed in the Glasgow Climate Pact. However, to achieve deep cuts in emissions without adversely impacting productivity or agricultural economic prosperity, we call for more studies that transcend disciplinary boundaries. Such studies should focus on not just GHG emissions, but multiple sustainability metrics (environmental, social, economic, institutional) and across scales (plot, field, region, continent, global) allowing more comprehensively evaluation of the wider co-benefits and trade-offs associated with GHG emissions mitigation (Harrison et al., 2021).

\section{AUTHOR CONTRIBUTIONS}

DS and $\mathrm{MH}$ wrote the manuscript. All authors contributed to editing the manuscript. All authors contributed to the article and approved the submitted version.

\section{ACKNOWLEDGMENTS}

We acknowledge Meat and Livestock Australia (Project No. B.CCH.2121 Sustainable Pathways to CN30), the Federal Ministry of Food and Agriculture Germany (BMEL, project HydroN2O, ptBLE-FKz 28-1-B2.04116), and the University of Tasmania for partially funding this research. 


\section{REFERENCES}

Alcock, D. J., Harrison, M. T., Rawnsley, R. P., and Eckard, R. J. (2015). Can animal genetics and flock management be used to reduce greenhouse gas emissions but also maintain productivity of wool-producing enterprises? Agric. Syst. 132, 25-34. doi: 10.1016/j.agsy.2014.06.007

Chang-Fung-Martel, J., Harrison, M. T., Rawnsley, R., Smith, A. P., and Meinke, H. (2017). The impact of extreme climatic events on pasture-based dairy systems: A review. Crop Pasture Sci. 68, 1158-1169. doi: 10.1071/CP16394

Christie, K. M., Rawnsley, R. P., Harrison, M. T., and Eckard, R. J. (2014). Using a modelling approach to evaluate two options for improving animal nitrogen use efficiency and reducing nitrous oxide emissions on dairy farms in southern Australia. Anim. Prod. Sci. 54, 1960-1970. doi: 10.1071/AN14436

Christie, K. M., Smith, A. P., Rawnsley, R. P., Harrison, M. T., and Eckard, R. J. (2018). Simulated seasonal responses of grazed dairy pastures to nitrogen fertilizer in SE Australia: Pasture production. Agric. Syst. 166, 36-47. doi: 10.1016/j.agsy.2018.07.010

Christie, K. M., Smith, A. P., Rawnsley, R. P., Harrison, M. T., and Eckard, R. J. (2020). Simulated seasonal responses of grazed dairy pastures to nitrogen fertilizer in SE Australia: N loss and recovery. Agric. Syst. 182, 102847. doi: 10.1016/j.agsy.2020.102847

Daum, D., and Schenk, M. K. (1996). Gaseous nitrogen losses from a soilless culture system in the greenhouse. Plant Soil 183, 69-78. doi: $10.1007 / \mathrm{BF} 02185566$

Harrison, M. T., Cullen, B. R., Mayberry, D. E., Cowie, A. L., Bilotto, F., Badgery, W. B., et al. (2021). Carbon myopia: the urgent need for integrated social, economic and environmental action in the livestock sector. Global Change Biol. 27, 5726-5761. doi: 10.1111/gcb.15816

Harrison, M. T., Cullen, B. R., Tomkins, N. W., McSweeney, C., Cohn, P., and Eckard, R. J. (2016). The concordance between greenhouse gas emissions, livestock production and profitability of extensive beef farming systems. Anim. Produc. Sci. 56, 370-384. doi: 10.1071/AN15515

Harrison, M. T., Evans, J. R., Dove, H., and Moore, A. D. (2011). Recovery dynamics of rainfed winter wheat after livestock grazing 2. light interception, radiation-use efficiency and dry-matter partitioning. Crop Pasture Sci. 62, 960-971. doi: 10.1071/CP11235

Harrison, M. T., Evans, J. R., and Moore, A. D. (2012). Using a mathematical framework to examine physiological changes in winter wheat after livestock grazing: 1. model derivation and coefficient calibration. Field Crops Res. 136, 116-126. doi: 10.1016/j.fcr.2012.06.015

Harrison, M. T., Jackson, T., Cullen, B. R., Rawnsley, R. P., Ho, C., Cummins, L., et al. (2014). Increasing ewe genetic fecundity improves whole-farm production and reduces greenhouse gas emissions intensities: 1. sheep production and emissions intensities. Agric. Syst. 131, 23-33. doi: 10.1016/j.agsy.2014. 07.008
Ho, C. K. M., Jackson, T., Harrison, M. T., and Eckard, R. J. (2014). Increasing ewe genetic fecundity improves whole-farm production and reduces greenhouse gas emissions intensities: 2. Economic performance. Anim Prod. Sci. 54, 1248-1253. doi: 10.1071/AN14309

IPCC (2014). Climate Change 2014: Mitigation of Climate Change. Contribution of Working Group III to the Fifth Assessment Report of the Intergovernmental Panel on Climate Change [Edenhofer, O., R. Pichs-Madruga, Y. Sokona, E. Farahani, S. Kadner, K. Seyboth, A. Adler, I. Baum, S. Brunner, P. Eickemeier, B. Kriemann, J. Savolainen, S. Schlömer, C. von Stechow, T. Zwickel and J.C. Minx (eds.)]. Cambridge, New York, NY: Cambridge University Press.

Smith, P., Martino, D., Cai, Z., Gwary, D., Janzen, H., Kumar, P., et al. (2008). Greenhouse gas mitigation in agriculture. Philos. Trans. R Soc. Lond. B Biol. Sci. 363, 789-813. doi: 10.1098/rstb.2007.2184

Sokolov, V., VanderZaag, A., Habtewold, J., Dunfield, K., Tambong, J. T., WagnerRiddle, C., et al. (2020). Acidification of residual manure in liquid dairy manure storages and its effect on greenhouse gas emissions. Front. Sustain. Food Syst. 4:568648. doi: 10.3389/fsufs.2020.568648

Sommer, S. G., Clough, T. J., Balaine, N., Hafner, S. D., and Cameron, K. C. (2017) Transformation of organic matter and the emissions of methane and ammonia during storage of liquid manure as affected by acidification. J. Environ. Q. 46, 514-521. doi: 10.2134/jeq2016.10.0409

UNFCCC (2021). United Nations Framework Convention on Climate Change. Decision -/CP.26 Glasgow Climate Pact. Available online at: https://unfccc. $\mathrm{int} /$ sites/default/files/resource/cop26_auv_2f_cover_decision.pdf (accessed December 24, 2021).

Conflict of Interest: The authors declare that the research was conducted in the absence of any commercial or financial relationships that could be construed as a potential conflict of interest.

Publisher's Note: All claims expressed in this article are solely those of the authors and do not necessarily represent those of their affiliated organizations, or those of the publisher, the editors and the reviewers. Any product that may be evaluated in this article, or claim that may be made by its manufacturer, is not guaranteed or endorsed by the publisher.

Copyright (C) 2022 Schwarz, Harrison and Katsoulas. This is an open-access article distributed under the terms of the Creative Commons Attribution License (CC BY). The use, distribution or reproduction in other forums is permitted, provided the original author(s) and the copyright owner(s) are credited and that the original publication in this journal is cited, in accordance with accepted academic practice. No use, distribution or reproduction is permitted which does not comply with these terms. 